\title{
Pasar modal syariah di Indonesia
}

\author{
Lisna \\ Jurusan perbankan syariah ,pakultas ekonomi dan bisnis islam, universitas islam \\ Negeri Alauddin Makassar \\ Email : lisnasapia@gmail.com
}

\begin{abstract}
Abstrak
Pertumbuhan pasar perbankan dan asuransi syariah telah mendorong kebutuhan pasar akan keperluan produk produk yang mampu mengatasi masalah lekuiditas industri keuangan syariah.kehadiran pasar modal berbasis intekrasi produk syariah di Indonesia di harapkan dapat membantu bank dan asuransi syariah mengoptimalkan penggunaan sumber dana yang tersedia sesuai dengan prinsip syariah sembari menjaga keseimbangan antara lekuiditas dan tingkat keuntungan selain itu,kehadiran produk syariah di pasar modal Indonesia juga memberi peluang berinvestasi bagi masyarakat yang menyakini bahwa produk investasi konvensional mengandung elemen-elemen yang di harapkan syariah.
\end{abstract}

\section{Kata kunci : kebijakan permodalan dalam syariah}

\section{PENDAHULUAN}

Pasar modal (capital market) merupakan pasar untuk berbagai instrumen keuangan jangka panjang yang bisa diperjual belikan, baik dalam bentuk utang maupun modal sendiri. Jika pasar modal merupakan pasar untuk surat berharga jangka panjang, maka pasar uang (money market) pada sisi yang lain merupakan pasar surat berharga jangka pendek. Adapun instrumen keuangan yang diperjual belikan di pasar modal seperti saham, obligasi, warran, right, obligasi konvertibel dan berbagai produk turunan (derivatif ) seperti opsi (put atau call), sedangkan dipasar uang diperjual belikan antara lain Sertifikat Bank Indonesia (SBI), Surat Berharga Pasar Uang (SBPU) dan lainlain.1Keberadaan pasar modal merupakan suatu realitas dan fenomena terkini ditengah-tengah kehidupan umat Islam di abad modern ini, bahkan hampir negara-negara di seluruh. penjuru dunia manapun telah menggunakan pasar modal

sebagai instrumen penting ekonomi untuk berinvestasi dan

juga pasar modal telah menarik perhatian banyak kalangan pengusaha dan investor untuk terlibat didalamnya.Praktek kegiatan ekonomi konvensional, terutama melalui kegiatan di pasar modal yang mengandung unsur spekulasi (garar) dan menjadikan sistem riba sebagai landasan operasionalnya, ternyata telah menjadi hambatan psikologis bagi umat Islam. Akan tetapi pesatnya perkembangan ekonomi ayariah, menuntut adanya instrumen keuangan sebagai sarana pendukung. Instrumen keuangan syariah bisa diwujudkan kedalam berbagai bentuk lembaga pembiayaan seperti halnya lembaga pasar modal, sehingga keberadaan pasar modal syariah di Indonesia diharapkan akan menjadi media alternatif berinvestasi secara halal melalui pembiayaan usaha disektor riil.2Dengan keberadaan pasar modal syariah di Indonesia, maka perlu disusun prinsip-prinsip syariah apa saja yang harus dilaksanakan didalamnya dan menjelaskan transaksi-transaksi apa saja yang yang ada di pasar modal yang tidak diperbolehkan pada pasar modal syariah di Indonesia. 


\section{Landasan teori}

\section{Saham Syariah}

Tidak ada yang sulit jika Anda ingin mencoba berinvestasi pada jenis saham syariah. Cara berinvestasinya sama saja dengan berinvestasi pada saham pada umumnya. Anda cukup mendatangi website atau sosial media perusahaan sekuritas, kemudian melakukan pembukaan akun dan setelah itu langsung bisa membeli dan menjual saham Syariah. Namun, tentu membeli saham syariah tidaklah sama dan semudah membeli kue di toko. Ada beberapa hal yang mesti Anda perhatikan sebelum akhirnya dapat memiliki saham syariah yang diidamkan.

BerikutBerikut beberapa langkah yang perlu Anda lakukan saat ingin berinvestasi saham Syariah :

1Kenali saham syariah yang diinginkan

Sangatlah penting untuk mengetahui terlebih dulu seluk-beluk saham yang Anda inginkan sebelum membeli melalui perusahaan sekuritas ataupun agen saham lainnya. Untuk saham syariah, yakinkan terlebih dulu saham yang Anda inginkan ada di dalam Daftar Efek Syariah yang diterbitkan oleh Otoritas Jasa Keuangan (OJK) atau pihak yang mendapatkan persetujuan dari OJK.

Daftar Efek Syariah (DES) merupakan kumpulan efek yang tidak bertentangan dengan prinsipprinsip syariah di pasar modal. Untuk menetapkan Daftar Efek Syariah, dilakukan review setiap enam bulan sekali.Review Daftar Efek Syariah (DES) yang diterbitkan oleh OJK dilakukan secara periodik dan insidental. Penerbitan secara periodik dilakukan setiap bulan Mei dan November, berlaku efektif setiap tanggal 1 Juni dan tanggal 1 Desember. Penerbitan secara insidental dilakukan sewaktu-waktu saat terjadi aksi korporasi dari emiten, seperti adanya penerbitan saham perdana (IPO) sebuah emiten di Bursa Efek Indonesia (BEI).

Adapun Review yang dilakukan pada Daftar Efek Syariah (DES) adalah sebagai berikut:

Kegiatan usaha yang dilakukan tidak bertentangan dengan prinsip syariah.Total utang yang berbasis bunga dibandingkan dengan total aset tidak lebih dari 45\%Total pendapatan bunga dan pendapatan tidak halal lainnya dibandingkan dengan total pendapatan usaha dan pendapatan lain-lain tidak lebih dari 10\%.Apabila saham dari perusahaan tersebut memenuhi kriteria daftar efek Syariah, maka sahamnya otomatis termasuk sebagai saham Syariah. Daftar Efek Syariah tersebut akan menjadi pedoman bagi pihak terkait antara lain Bursa Efek Indonesia dalam membuat indeks Syariah seperti ISSI dan JII, JII70 akan berpedoman pada DES. Rekda Dana Syariah, asuransi Syariah dan dana pension Syariah juga akan berinvestasi pada efek Syariah. Selain itu, investor yang membuka akun melalui SOTS juga hanya berinvestasi pada efek-efek Syariah.Datangi perusahaan sekuritas

2.Setelah Anda memahami apakah perusahaan yang Anda inginkan masuk dalam Dafta Efek Syariah (DES), segera datangi perusahaan sekuritas tepercaya yang menawarkan saham syariah. Kini sudah ada Sharia Online Trading System (SOTS). Pastikan perusahaan sekuritas tersebut terdaftar dan diakui keberadaannya oleh OJK. Pembukaan rekening tidak hanya dapat dilakukan melalui dating secara langsung ke persuhaan sekuritas pemilik SOTS, namun saat ini semua proses tersebut bisa dilakukan secara online tanpa harus bertemu langsung.

\section{Minta penjelasan kepada}

Penasihat investasi Jika Anda kurang memahami, mintalah penjelasan secara rinci kepada petugas perusahaan sekuritas untuk menjadi pembanding dan pelengkap informasi dari emiten yang Anda ingin- kan. Setelah itu, isi formulir yang diperlukan. 


\section{Investasi pada reksa dana Syariah}

Jika ragu untuk berinvestasi langsung pada saham syariah di pasar modal, karena anda seorang pemula, maka ada reksa dana syariah. Anda akan dibantu oleh perusahaan Manajer Investasi dan bank custodian untuk mengelola portofolio investasi anda dalam bentuk reksa dana syariah. Jika anda memilih jenis reksa dana saham, maka manajer investasi akan memilihkan saham-saham Syariah terbaik yang liquid sebagai portofolionya untuk anda.

\section{Keuntungan investasi saham}

Dividen : Jika perusahaan memiliki laba dan laba tersebut disepakati untuk dibagikan kepada pemegang saham, semua pemegang saham berhak atas pembagian laba perusahaan tersebut.

Capital Gain : Jika harga saham yang dimiliki oleh investor naik dari harga saham pada saat dibeli, selisih harga jual tersebut menjadi keuntungan pemegang saham

\section{Risiko Investasi}

Capital Loss, yaitu penurunan harga sahamRisiko Likuidasi, yaitu risiko yang terjadi ketika perusahaan dinyatakan bangkrut atau bubaran.

\section{Metode penelitian}

1.jenis penelitian dan pendekatan

Dalam penelitian interpretasi regulator terhadap kebijakan inteqrasi produk syariah di pasar modal,penulis memiliki metode penelitian kualitatif ,penelitian kualitatif beranjak dari peradiqma ilmu bahwa satu-satunya kenyataan yang dikonstruksikan oleh individu adalah apa yang terlihat dalam penelitian

\section{2.sumber data}

Sumber data buku ini terdiri dari kaka-kata tindakan ,sumber tertulis dan data statistik .sumber data tertulis berupa masterplan pasar modal Indonesia 2004-2009. dan 2005-2009keputusan ketua Bapepam dan kep-180/BL/2009 dan penerbit daftar efek syariah. Kep-208/BL/2012tentang penerbit 24 April 2012 lampiran peraturan keputusan bapepanm dan KL tentang daftar efek syariah setiap enam bulan sekali di tinjau ulang fatwa DSN-MUI terkait produk syariah di pasar, hasil kajian tim depkeu Bapepam dan lainya yang berhubungan dengan fokus utama dalam penelitian

3. Teknik analisis data

Analisis data kulitatif dilakukan dengan analisis usia berupa penelusuran data dalam regulasi produk syariah yaitu membandingkan antara konsep ideal dan kenyataan yang terjadi bahan atau sumber data analisis dengan menggunakan logika deduktif yaitu melalui pembahasan dan analisis dari kaifah-kaidah terkait dengan persoalan yang dibahas lalu menjabarkan dalam yang diteliti,yaitu produk syariah di pasar 
Hasil pembahasan

Dilihat dari sisi syariah, pasar modal adalah salah satu sarana atau produk muamalah. Transaksi didalam pasar modal, menurut prinsip hukum syariah tidak dilarang atau dibolehkansepanjang tidak terdapat transaksi yang bertentangan dengan ketentuan yang telah digariskan oleh syariah.Diantara yang dilarang oleh syariah adalah transaksi yang mengandung bunga dan riba

>. Larangan transaksi bunga (riba_sangat jelas, karena itu transaksi dipasar modal yang didalamnya terdapat bunga (riba

>) tidak diperkenankan oleh Syariah.Syariah juga melarang transaksi yang didalamnya terdapat spekulasi dan mengandung garar atau ketidakjelasan yaitu transaksi yang didalamnya dimungkinkan terjadinya penipuan. Termasuk dalam pengertian ini antara lain: melakukan penawaran palsu (bai' najsy); transaksi atas barang yang belum dimiliki (short selling); menjual sesuatu yang belum jelas (bai' al-ma'du

$>$ M); menyebarluaskan informasi yang menyesatkan atau memakai informasi orang dalam untuk memperoleh keuntungan transaksi yang dilarang (insider trading) dan pembelian untuk penimbunan efek

\section{KESIMPULAN}

Prinsip syariah di pasar modal adalah prinsip hukum Islam dalam kegiatan syariah di pasar moderen berdasarkan fatwa dewan syari'ah nasional-majelis ulama Indonesia (DSNMUI)sepanjang fatwa dimanah tidak bertentangan dengan peraturan prinsip syariah di pasar modal dan /atau peraturan otoritas jasa keuangan lainnya yang dilakukan fatwa SDN-MUI

\section{UCAPAN TERIMAH KASIH}

Pertama-tama saya ucapkan terimah kasih kepada yang maha kuasa yang memberi kesehatan dan kekuatan untuk menjalan kan salah satu kewajiban sebagai masahiswa dan tak lupa pula saya berterimah kasih kepada kedua orang tau saya dan saya berterimah kasih para pembuat buku yang berjudul pasar modal syariah di Indonesia

PUSTAKA

- Burhanuddin S, Pasar Modal Syari'ah (Tinjauan Hukum), Yoyakarta, UII Press, 2008.Dawud, AbuSunan Abi> Da>wud Juz 2, Beirut, Dar al - kutub al -llmiyah, 1996

- Hanbal, Imam Ahmad bin, Musnad al - Ima>m Ah\}mad bin Hanbal Juz 5, Beirut, Dar al kutub al - Ilmiyah, 1993Karim, Adiwarman A, Bank Islam Analisis Fiqih dan Keuangan, Jakarta, PT Raja Grafindo Persada, 2006

- Majah, Ibnu, Sunan Ibnu Ma>jah Juz 1, Beirut, Dar al - kutub al -Ilmiyah, 2008Nasa> i, Sunan an - Nasa> i Juz 7, Beirut, Dar al - kutub al -llmiyah, 1930

- Qardhawi, Yusuf, Halal dan Haram Dalam Islam, Surabaya, PT Bina Ilmu Surabaya, 2003 Rodoni, Ahmad dan Abdul Hamid, Lembaga Keuangan Syari'ah, Jakarta, Zikrul Hakim, 2008

- Sudarsono, Heri, Bank dan Lembaga Keuangan Syari'ah Deskripsi dan llustrasi, Yogyakarta : EKONISIA, 2007. 
- Syarifuddin, Amir, Garis - Garis Besar Fiqh, Jakarta, Prenada Media, 2003

- Thayyar, Ath, Abdullah bin Muhammad...dkk, Ensiklopedi Fiqih Muamalah dalam Pandangan Empat Madzhab, Penerjemah Miftahul Khairi, Yogyakarta, Maktabah AlHanif, Cetakan I, 2009

- Departemen Agama RI, Al-Qur'an Terjemahan Per-kata, Bandung】, PT. Syaamil Al-Qur'an, 2007Fatwa Dewan Syariah Nasional No.40/DSN-MUI/X/2003 Tentang Pasar Modal Dan Pedoman Umum Penerapan Prinsip Syariah Di Bidang Pasar Modal

- Fatwa Dewan Syari'ah Nasional No: 80/DSN-MUI/III/2011 Tpentang Penerapan Prinsip syariah Dalam Mekanisme Perdagangan Efek Bersifat Ekuitas Di Pasar Reguler Bursa Efek 